\title{
Remote sensing of redberry juniper in the Texas rolling plains
}

\author{
J. H. EVERITT, C. YANG, B. J. RACHER, C. M. BRITTON, AND M. R. DAVIS
}

Authors Everitt, Yang, and Davis are range scientist, agricultural engineer, and pilot, USDA-ARS, 2413 E. Highway 83, Weslaco, Tex. 78596; and graduate student and professor, Department of Range, Wildlife, and Fisheries, Texas Tech University, Lubbock, Tex. 79409-2125.

\begin{abstract}
Redberry juniper (Juniperus pinchotii Sudw.) is a noxious shrub or small tree that invades rangelands in northwest Texas. Field reflectance measurements showed that redberry juniper had lower visible and higher near-infrared (NIR) reflectance than associated species and mixtures of species in February. The low visible reflectance of redberry juniper was due to its darker green foliage than associated species, whereas its high NIR reflectance was attributed to its greater vegetative density than associated vegetation. Redberry juniper had a distinct reddishbrown image tonal response on color-infrared aerial photographs obtained in February. Computer analysis of a colorinfrared photographic transparency showed that redberry juniper infestations could be quantified. An accuracy assessment performed on the classified image had a user's accuracy of $100 \%$ and a producer's accuracy of $94 \%$ for redberry juniper.
\end{abstract}

Key Words: color-infrared photography, reflectance, digital image analysis, accuracy assessment, Juniperus

Redberry juniper (Juniperus pinchotii Sudw.) is a sprouting, evergreen shrub or small tree rarely reaching a height of $7 \mathrm{~m}$ that occurs on rangelands in Oklahoma, New Mexico, Arizona, and Texas (Correll and Johnston 1979). Historically, west Texas populations of redberry juniper were restricted primarily to buttes and escarpments but since the 1860's have expanded into grasslands (Ellis and Schuster 1968, West 1991). Redberry juniper is a major invader of fertile lowland ranges in northwest Texas, particularly those below, or associated with rough shallow-soiled rangeland (Scifres 1980). Ansley et al. (1995) estimated that redberry juniper had increased its range by $61 \%$ from 1948 to 1982 , and occurred on 4.1 million ha of Texas rangelands. Its fairly recent expansion in range is blamed on suppresssion of naturally occurring fires, severe overgrazing, and recurrent droughts (Smeins 1980, 1990).

On some sites redberry juniper has value as a soil stabilizer and furnishes cover for wildlife. However, it is considered a low value browse for both livestock and wildlife (Scifres 1980). Several methods have been used to control redberry juniper including bulldozing, broadcast sprays and pelleted herbicides, and fire (Scifres 1980, Steuter and Britton 1983, Steuter and

Thanks are extended to M. A. Alaniz and A. Gomez for their assistance in obtaining ground reflectance measurements. The authors also thank I. Cavazos for his image processing work.

Manuscript accepted 13 Aug. 2000.

\section{Resumen}

El "Redberry juniper" (Juniperus pinchotii Sudw.) es un arbusto o árbol pequeño nocivo que invade los pastizales del Noroeste de Texas. Las medidas de reflectancia de campo muestran que en febrero el "Redberry juniper" tiene una menor reflectancia visible y una mayor reflectancia cercana al infrerojo (NIR) que las especies asociadas y las mezclas de especies. La baja reflectancia visible del "Redberry juniper" se debio a que su follaje es de color verde más obscuro que el de las especies asociadas, mientras que su alta reflectancia NIR se atribuyó a que tenia una mayor densidad vegetativa que la vegetación asociada. En las fotografías aéreas infrarrojas de color obtenidas en febrero el "Redberry juniper" tuvo una respuesta de imagen tonal rojiza-café distinta. El análisis de computadora de una transparencia fotográfica infrarroja de color mostró que las infestaciones de "Redberry juniper" pudieron ser cuantificadas. Para el caso de "Redberry juniper", una evaluación de la exactitud realizada en la imagen calsificada tuvo una exactitud del usuario del $100 \%$ y una exactitud del productor del $94 \%$

Wright 1983).

Due to the generally great expanse and inaccessibility of many rangeland areas, rapid and low-cost evaluation procedures are needed to acquire information for proper management of these areas. This information would be useful to range managers and individual land owners. Remote sensing techniques offer the advantage of rapid acquisition of data with generally short turnaround time and a procedure considerably less costly than ground surveys (Tueller 1982, Everitt et al. 1992). Plant canopy reflectance measurements have been used to distinguish noxious brush and weed species, and color-infrared aerial photography has been used extensively to remotely detect these undesirable species in rangeland areas (Gausman et al. 1977, Myhre 1987, Everitt et al. 1995, Driscoll et al. 1997, Anderson et al. 1999).

The objectives of this study were: (a) to establish the plant canopy reflectance characteristics of redberry juniper to facilitate its detection on remotely sensed imagery; and (b) to evaluate color-infrared aerial photography for distinguishing redberry juniper on northwest Texas rangelands.

\section{Materials and Methods}

This study was conducted in northwest Texas. Study sites were located near Justiceburg $\left(32^{\circ} 59 \mathrm{~N} 101^{\circ} 12 \mathrm{~W}\right)$, Dickens $\left(33^{\circ} 31 \mathrm{~N}\right.$ $\left.100^{\circ} 36 \mathrm{~W}\right)$, Quanah (34 $\left.10 \mathrm{~N} 99^{\circ} 52 \mathrm{~W}\right)$, Maryneal $\left(32^{\circ} 17 \mathrm{~N}\right.$ 


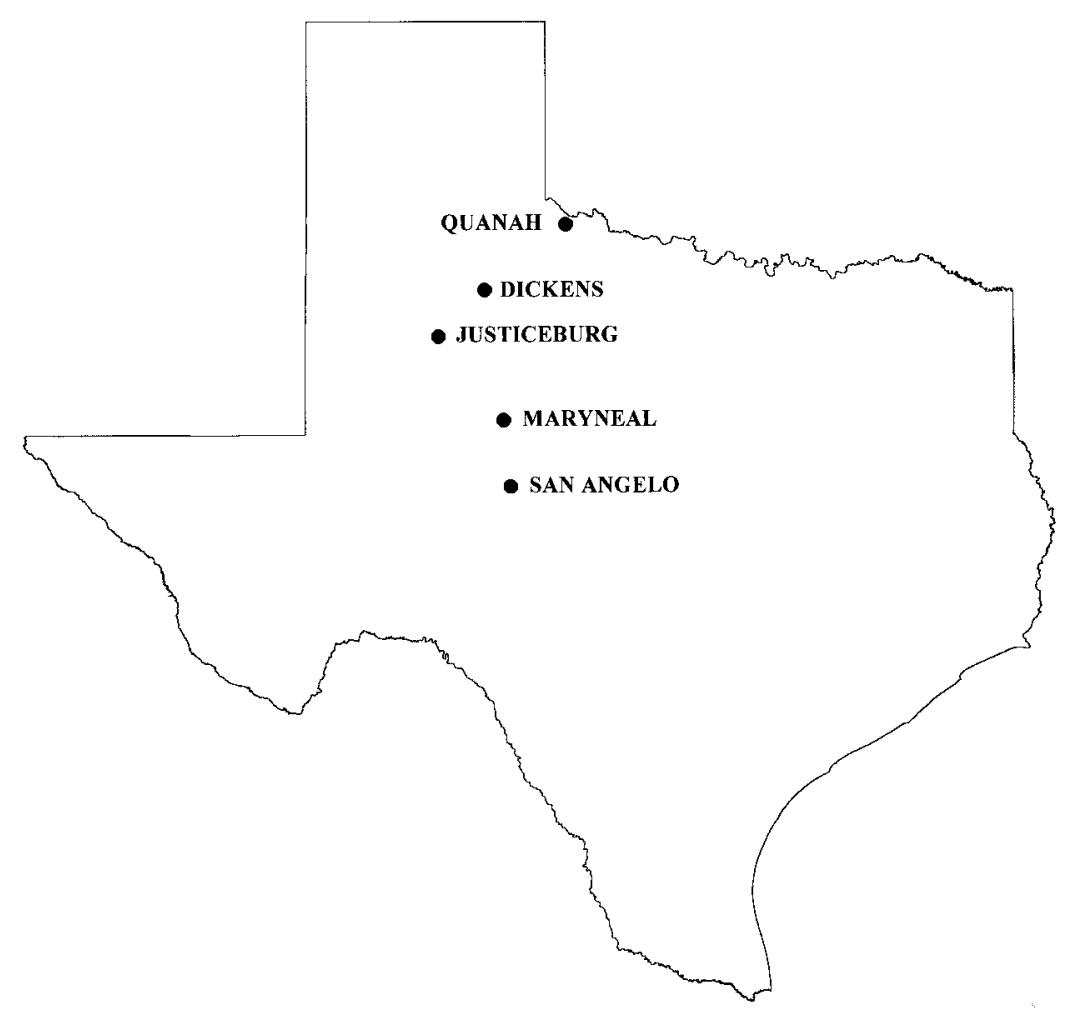

Fig. 1. Locations of study sites in Texas.

$\left.100^{\circ} 29 \mathrm{~W}\right)$, and San Angelo $31^{\circ} 38 \mathrm{~N} 100^{\circ}$ $32 \mathrm{~W}$ ) in the Rolling Plains resource area (Hatch et al. 1990) (Fig. 1). Aerial photography, radiometric reflectance measurements, computer image analysis, and ground truth observations were conducted for this study. Reflectance measurements were made to establish the spectral characteristics of redberry juniper, associated plant species, and soil to help interpret

Table 1. Dates and locations that field reflectance measurements and aerial photography were acquired in northwest Texas.

\begin{tabular}{|c|c|c|}
\hline Location & Reflectance & Photography ${ }^{1}$ \\
\hline Justiceburg & $\begin{array}{l}30 \text { June }^{2} \text { 1998; } \\
23 \text { Feb. }^{3} \text { 28 June }{ }^{4}, \\
18 \text { Aug. }{ }^{4}, \text { \& } 22 \text { Sept. }^{4}, 1999\end{array}$ & $\begin{array}{l}30 \text { June } 1998, \\
23 \text { Feb., } 29 \text { July, \& } \\
22 \text { Sept. } 1999\end{array}$ \\
\hline Maryneal & 18 Aug. ${ }^{5} 1999$ & \\
\hline Dickens & & $\begin{array}{l}30 \text { June } 1998, \\
23 \text { Feb. \& } 22 \text { Sept. } 1999\end{array}$ \\
\hline San Angelo & & $\begin{array}{l}9 \text { July } 1998 \\
23 \text { Feb. \& } 22 \text { Sept. } 1999\end{array}$ \\
\hline Quanah & & $\begin{array}{l}9 \text { July } 1998 ; \\
23 \text { Feb. \& } 22 \text { Sept. } 1999\end{array}$ \\
\hline
\end{tabular}

${ }^{P}$ Photographs were taken at scales of 1:1,200, 1:2,500, 1:4,000, 1:5,000, 1:6,000, 1:7,500, and 1:8,500.

${ }^{2}$ Reflectance measurements were made on redberry juniper, honey mesquite, yucca, plains prickly pear, tobosa grass, mixed herbaceous species (grasses and broadleafed herbs), and bare soil.

${ }^{3}$ Reflectance measurements were made on redberry juniper, yucca, plains prickly pear, tobosa grass, mixed herbaceous species, and bare soil

${ }^{4}$ Reflectance measurements were made on redberry juniper, honey mesquite, yucca, plains prickly pear, tobosa grass, annual broomweed, mixed herbaceous species, and bare soil.

${ }^{5}$ Reflectance measurements were made on redberry juniper, honey mesquite, yucca, plains prickly pear, mixed herbaceous species, and bare soil.
Reflectance measurements were made on each of 10 randomly selected plant canopies of each species or species mixture and soil surfaces with a Barnes ${ }^{1}$ modular multispectral radiometer (Robinson et al. 1979). Measurements were made in the visible green $(0.52$ to $0.60 \mu \mathrm{m})$, visible red (0.63 to $0.69 \mu \mathrm{m})$, and NIR (0.76 to 0.90 $\mu \mathrm{m})$ spectral bands with a sensor that had a 15-degree field-of-view placed 1.0 to 1.5 $\mathrm{m}$ above each plant and soil target.

The area within the sensor field-of-view ranged from 0.26 to $0.39 \mathrm{~m}$. Reflectance measurements were made between 1100 and 1500 hours Central Standard Time under sunny conditions. Measurements of redberry juniper and honey mesquite (Prosopis glandulosa Torr.) were usually made from a stepladder. Honey mesquite was not measured in February 1999 because it is deciduous (Table 1). Annual broomweed (Amphiachyris dracunculoides DC.) was not measured in June 1998 and February 1999 because it was not available in sufficient amounts and was not present, respectively. Overhead vertical photographs were obtained of the plant canopies and bare soil measured with the radiometer to help interpret the reflectance data. Radiometric measurements were corrected to reflectance using a barium sulfate standard (Richardson 1981).

Green, red, and NIR reflectance data were analyzed using analysis of variance techniques. Duncan's multiple range test was used to test statistical significanace at the 0.05 probability level among means (Steel and Torrie 1980).

Kodak Aerochrome color-infrared $(0.50$ to $0.90 \mu \mathrm{m}$ ) type 2443 film was used for aerial photographs. Color-infrared film is sensitive in the visible green $(0.50$ to 0.60 $\mu \mathrm{m})$, visible red $(0.61$ to $0.75 \mu \mathrm{m})$, and NIR (0.76 to $0.90 \mu \mathrm{m})$ spectral regions. Photographs were obtained with a Fairchild type K-37 large format $(23 \mathrm{~cm} \mathrm{x}$ $23 \mathrm{~cm}$ ) mapping camera. The camera was equipped with a $305 \mathrm{~mm}$ lens with an aperture setting of $\mathrm{f} 11$ at $1 / 250 \mathrm{sec}$. A fixedwing aircraft, equipped with a camera port in the floor, was used for obtaining aerial photography. The camera was maintained in a nadir position during all image acquisition. Aerial photographs were acquired between 1130 and 1400 hours Central Standard Time under sunny conditions.

Two color-infrared photographic transparencies (1:5,000 scale) of a study site near Justiceburg obtained on 23 February

\footnotetext{
${ }^{1}$ Trade names are included for the benefit of the reader and do not imply endorsement of or a preference for the product listed by the USDA.
} 
and 29 July 1999, respectively, were digitized to perform a computer classification and accuracy assessment on each photograph. A Trimble differential global positioning system (GPS) Pathfinder Pro XRS system that provided submeter accuracy was used in the field to establish control points on the digitized photographic transparencies. The transparencies were scanned at 600 dpi and had a pixel resolution of $0.40 \mathrm{~m}$. Erdas Imagine software (Version 8.3) was used to georeference the transparencies. The images were subjected to an Iterative Self-Organizing Data Analysis (ISODATA) which performs unsupervised classifications on the basis of specified iterations and recalculates statistics for each iteration (Erdas 1997). The ISODATA technique uses minimum spectral distance to assign a cluster for each selected pixel. It begins with arbitrary cluster means, and each time the clustering repeats, the means of these clusters are shifted. The new cluster means are used for the iteration. Initially the unsupervised classification created 10 classes at the 99\% convergence threshold (the maximum percentage of pixels cluster assignments go unchanged between iterations). Some of the initial categories were combined resulting in 4 final categories. The classes consisted of redberry juniper, mixed vegetation, bare soil, and honey mesquite. Honey mesquite was defoliated in the February photograph. For accuracy assessment, 100 points were assigned to the 4 classes in a stratified random pattern. The geographic coordinates of these points were determined and the GPS was used to navigate to the points in ground truthing. The ground sampling sites for all classes had an area much larger than the image pixel size or GPS error.

\section{Results and Discussion}

\section{Reflectance measurements}

Mean light reflectance measurements of redberry juniper, associated plant species and mixtures of species, and bare soil at 3 wavelengths from 6 sampling dates near Justiceburg and Maryneal are shown in Table 2. In June 1998 at the Justiceburg site, bare soil (sand and rock) had higher green, red, and NIR reflectance than the associated plant species. Redberry juniper had lower green reflectance than the other plant species, mixtures of species, and soil. At the red wavelength, redberry juniper and honey mesquite had similar reflectance values. The NIR reflectance of redberry juniper did not differ from that of honey mesquite and yucca (Yucca angustifolia Trel.).

Differences in visible reflectance among the plant species and mixtures of species was primarily attributed to differences in foliage color and subsequent plant pigments (Myers et al. 1983, Gausman 1985). Foliage colors varied from dark green for redberry juniper and honey mesquite, to light green for plains prickly pear (Opuntia polycantha Haw.) and yucca, to various shades of light green and graygreen for mixed herbaceous species and tobosa grass [Hilaria mutica (Buckl.)

Table 2. Mean light reflectance of redberry juniper, associated species and mixtures of species, and bare soil on 6 dates for the visible green, visible red, and near-infrared wavelengths. Measurements were made near Justiceburg and Maryneal, Tex.

\begin{tabular}{|c|c|c|c|c|}
\hline \multirow[b]{2}{*}{ Location and date } & \multirow{2}{*}{$\begin{array}{l}\text { Plant species, } \\
\text { mixture, or soil }\end{array}$} & \multicolumn{3}{|c|}{ Reflectance values ${ }^{1}$ for 3 wavelengths } \\
\hline & & green & red & near-infrared \\
\hline June 1998 & Honey mesquite & $5.6 \mathrm{~d}$ & $3.7 \mathrm{e}$ & $25.8 \mathrm{~b}$ \\
\hline \multirow[t]{6}{*}{ Justiceburg } & Plains prickly pear & $7.2 \mathrm{c}$ & $7.0 \mathrm{c}$ & $17.1 \mathrm{~d}$ \\
\hline & Redberry juniper & $4.3 \mathrm{e}$ & $3.0 \mathrm{e}$ & $24.0 \mathrm{bc}$ \\
\hline & Yucca & $7.2 \mathrm{c}$ & $6.1 \mathrm{~d}$ & $23.3 \mathrm{c}$ \\
\hline & Tobosa grass & $9.6 \mathrm{~b}$ & $9.7 \mathrm{~b}$ & $16.5 \mathrm{~d}$ \\
\hline & Mixed herbaceous species & $9.0 \mathrm{~b}$ & $9.2 \mathrm{~b}$ & $18.4 \mathrm{~d}$ \\
\hline & Bare soil & $14.4 \mathrm{a}$ & $17.7 \mathrm{a}$ & $28.2 \mathrm{a}$ \\
\hline February 1999 & Honey mesquite & $-^{2}$ & - & - \\
\hline \multirow[t]{6}{*}{ Justiceburg } & Plains prickly pear & $5.9 \mathrm{~d}$ & $5.4 \mathrm{c}$ & $14.3 \mathrm{~b}$ \\
\hline & Redberry juniper & $4.3 \mathrm{e}$ & $3.0 \mathrm{~d}$ & $23.3 \mathrm{a}$ \\
\hline & Yucca & $6.9 \mathrm{c}$ & $6.2 \mathrm{c}$ & $14.9 \mathrm{~b}$ \\
\hline & Tobosa grass & $7.9 \mathrm{~b}$ & 7.6.b & $13.2 \mathrm{~b}$ \\
\hline & Mixed herbaceous species & $7.9 \mathrm{~b}$ & $7.6 \mathrm{~b}$ & $14.1 \mathrm{~b}$ \\
\hline & Bare soil & $12.2 \mathrm{a}$ & $13.7 \mathrm{a}$ & $23.8 \mathrm{a}$ \\
\hline June 1999 & Annual broomweed & $6.7 \mathrm{de}$ & $4.5 \mathrm{e}$ & $33.0 \mathrm{a}$ \\
\hline \multirow[t]{7}{*}{ Justiceburg } & Honey mesquite & $4.9 \mathrm{f}$ & $3.0 \mathrm{f}$ & $8.8 \mathrm{~b}$ \\
\hline & Plains prickly pear & $7.2 \mathrm{~cd}$ & $6.5 \mathrm{~cd}$ & $18.4 \mathrm{e}$ \\
\hline & Redberry juniper & $4.6 \mathrm{f}$ & $3.1 \mathrm{f}$ & $24.8 \mathrm{c}$ \\
\hline & Yucca & $6.0 \mathrm{e}$ & $5.3 \mathrm{de}$ & $24.2 \mathrm{c}$ \\
\hline & Tobosa grass & $8.0 \mathrm{bc}$ & $7.3 \mathrm{bc}$ & $21.6 \mathrm{~d}$ \\
\hline & Mixed herbaceous species & $8.7 \mathrm{~b}$ & $8.3 \mathrm{~b}$ & $24.9 \mathrm{c}$ \\
\hline & Bare soil & $13.8 \mathrm{a}$ & $16.7 \mathrm{a}$ & $29.2 \mathrm{~b}$ \\
\hline August 1999 & Annual broomweed & $7.7 \mathrm{~cd}$ & $5.6 \mathrm{c}$ & $29.7 \mathrm{a}$ \\
\hline \multirow[t]{7}{*}{ Justiceburg } & Honey mesquite & 5.3 ef & $3.2 \mathrm{~d}$ & $28.0 \mathrm{a}$ \\
\hline & Plains prickly pear & $6.6 \mathrm{de}$ & $6.0 \mathrm{c}$ & $20.0 \mathrm{c}$ \\
\hline & Redberry juniper & $4.4 \mathrm{f}$ & $3.1 \mathrm{~d}$ & $24.3 \mathrm{~b}$ \\
\hline & Yucca & $7.5 \mathrm{~cd}$ & $6.1 \mathrm{c}$ & $28.1 \mathrm{a}$ \\
\hline & Tobosa grass & $8.5 \mathrm{bc}$ & $8.2 \mathrm{~b}$ & $18.2 \mathrm{c}$ \\
\hline & Mixed herbaceous species & $9.3 \mathrm{~b}$ & $9.4 \mathrm{~b}$ & $24.0 \mathrm{~b}$ \\
\hline & Bare soil & $14.7 \mathrm{a}$ & $16.3 \mathrm{a}$ & $28.5 \mathrm{a}$ \\
\hline August 1999 & Honey mesquite & $5.3 \mathrm{c}$ & $3.4 \mathrm{~d}$ & $28.8 \mathrm{a}$ \\
\hline \multirow[t]{5}{*}{ Maryneal } & Plains prickly pear & $7.4 \mathrm{~b}$ & $6.9 \mathrm{c}$ & $17.5 \mathrm{c}$ \\
\hline & Redberry juniper & $5.2 \mathrm{c}$ & $3.2 \mathrm{~d}$ & $25.1 \mathrm{~b}$ \\
\hline & Yucca & $7.9 \mathrm{~b}$ & $5.8 \mathrm{c}$ & $29.8 \mathrm{a}$ \\
\hline & Mixed herbaceous species & $8.5 \mathrm{~b}$ & $8.3 \mathrm{~b}$ & $22.6 \mathrm{~b}$ \\
\hline & Bare soil & $17.1 \mathrm{a}$ & $17.2 \mathrm{a}$ & $29.2 \mathrm{a}$ \\
\hline September 1999 & Annual broomweed & $6.1 \mathrm{~cd}$ & $3.9 \mathrm{de}$ & $29.3 \mathrm{ab}$ \\
\hline \multirow[t]{7}{*}{ Justiceburg } & Honey mesquite & $5.9 \mathrm{~cd}$ & $3.9 \mathrm{de}$ & $26.5 \mathrm{c}$ \\
\hline & Plains prickly pear & $6.6 \mathrm{c}$ & $5.4 \mathrm{c}$ & $19.3 \mathrm{e}$ \\
\hline & Redberry juniper & $4.7 \mathrm{~d}$ & $2.9 \mathrm{e}$ & $23.4 \mathrm{~d}$ \\
\hline & Yucca & $6.2 \mathrm{~cd}$ & $4.9 \mathrm{~cd}$ & $30.0 \mathrm{a}$ \\
\hline & Tobosa grass & $8.3 \mathrm{~b}$ & $7.7 \mathrm{~b}$ & $17.3 \mathrm{e}$ \\
\hline & Mixed herbaceous species & $7.9 \mathrm{~b}$ & $7.5 \mathrm{~b}$ & $18.1 \mathrm{e}$ \\
\hline & Bare soil & $14.8 \mathrm{a}$ & $16.0 \mathrm{a}$ & $27.7 \mathrm{bc}$ \\
\hline
\end{tabular}

${ }^{\mathrm{T}}$ Values within a column at each sampling date followed by the same letter do not differ significantly at the $5 \%$ probability level, according to Duncan's multiple range test.

${ }^{2}$ Honey mesquite is deciduous and consequently was not measured in February. 
that honey mesquite, redberry juniper, and yucca had greater vegetative density and less gaps (sun flecks) in their canopies than plains prickly pear, tobosa grass, and mixed herbaceous species. Internal leaf structure measurements were not made, but this could also contribute to the NIR reflectance measurements (Gausman 1974). The high visible reflectance of bare soil was due to its light gray-brown color, whereas its high NIR reflectance was attributed to sand and rocky surface particles (Bowers and Hanks 1965, Gerbermann et al. 1987).

In February 1999 at Justiceburg, redberry juniper had lower green and red reflectance than the associated plant species and mixtures of herbaceous species, and bare soil. At the NIR wavelength, redberry juniper and bare soil had similar reflectance values; however, redberry juniper had higher NIR reflectance than the associated plant species and mixtures of species. The lower visible and higher NIR reflectance of redberry juniper in February was due to its darker green foliage and greater vegetative density, respectively, than that of the associated plant species and mixtures of species. The lower vegetative density of the associated species and mixtures of species was attributed to their winter dormancy.

Reflectance data for June 1999 at Justiceburg indicated that redberry juniper could not be distinguished spectrally from honey mesquite at both the green and red wavelengths. At the NIR wavelength, redberry juniper, yucca, and mixed herbaceous species had similar reflectance values.

At the Justiceburg site in August 1999, the green and red reflectance of redberry juniper did not differ from that of honey mesquite. The NIR reflectance values of redberry juniper and mixed herbaceous species could not be separated. Reflectance measurements made at the Maryneal site in August 1999 showed that redberry juniper and honey mesquite had similar reflectance values at both the green and red wavelengths, whereas at the NIR wavelength the reflectance values of redberry juniper and mixed herbaceous species did not differ.

Spectral measurements made at Justiceburg in September 1999 indicated that the green reflectance of redberry juniper could not be distinguished from that of annual broomweed, honey mesquite, and yucca. At the red wavelength, redberry juniper had similar reflectance to that of annual broomweed and honey mesquite. The NIR reflectance of redberry juniper differed from that of the other associated plant species, mixtures of species, and bare soil in September.

These findings indicate that the optimum time to spectrally distinguish redberry juniper from associated species was in February when other species are dormant. Redberry juniper had much greater NIR reflectance than the other associated species in February. Thus, the discrimination of redberrry juniper on colorinfrared aerial photos should be best at this time.

\section{Aerial photography}

Figures 2A and 2B show color-infrared positive photographic prints obtained on 29 July and 23 February 1999, respectively, of a rangeland area infested with redberry juniper near Justiceburg. Both prints are portions of $23 \mathrm{~cm}$ photographs (1:5,000 scale). The arrow on the February photograph (Fig. 2B) points to the conspicuous reddish-brown image tone of redberry juniper. Redberry juniper has a similar tonal response throughout the image. Dormant mixed herbaceous species have variable bluegray tones, whereas bare soil, rocky soil areas, and roads have a whitish-gray tone. Dormant deciduous honey mesquite plants have a dark blue-gray image response. In the July photograph (Fig. 2A) the vegetation is in vigorous growing condition follow-

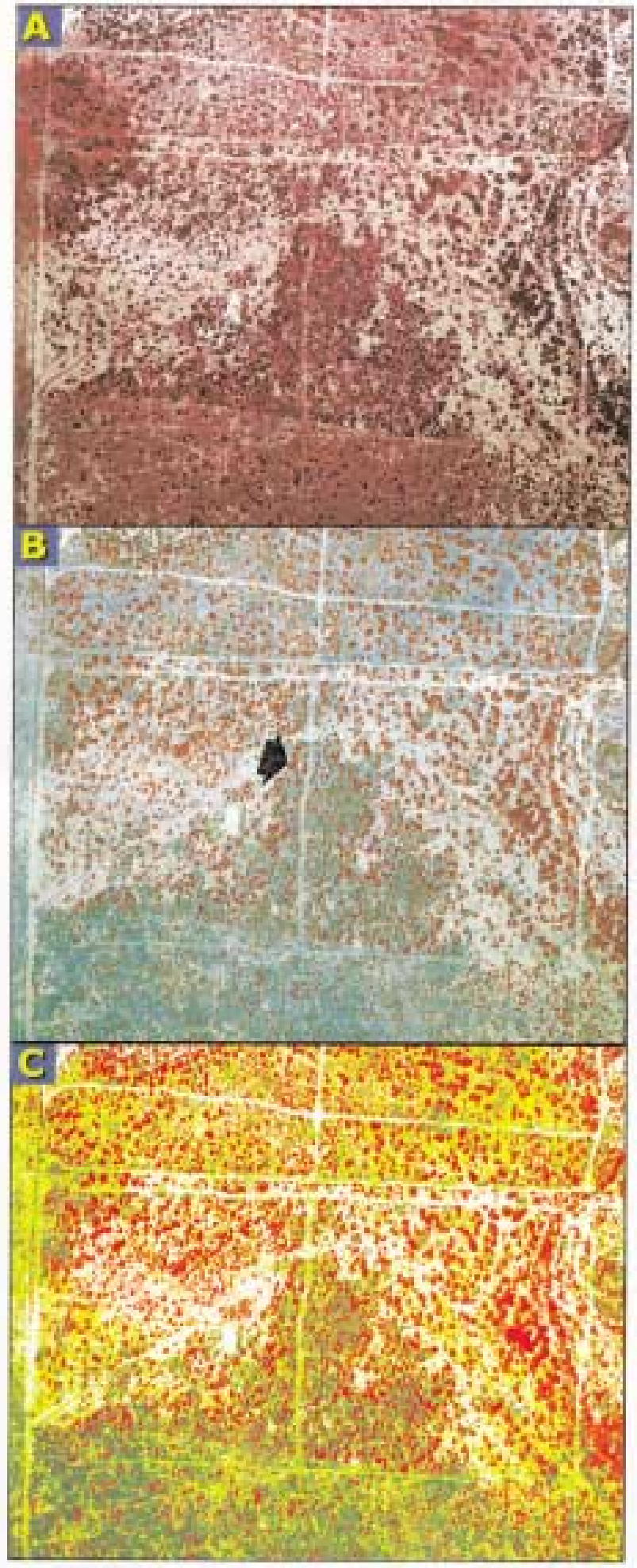

Fig. 2. Color-infrared photographic prints obtained on 29 July (print A) and 23 February (print B), 1999 of a rangeland area near Justiceburg, Texas. Both photos had an original scale of 1:5,000 and the area shown here is $590 \times 500 \mathrm{~m}$. The arrow on print $B$ points to the reddish-brown image tonal response of redberry juniper. Unsupervised computer classification (C) of print B. Color codes for the various landuse types are: red $=$ redberry juniper, yellow = mixed vegetation, green $=$ dormant honey mesquite, and white $=$ bare soil. 
ing optimum rainfall in June and early July. Consequently, most of the vegetation has high chlorophyll levels which contributes significantly to its various red and magenta tones on the color-infrared photograph. Redberry juniper and honey mesquite both have dark red image tones in the July photograph that can not be separated. This is apparent in the lower-center portion of the photograph where a moderate stand of honey mesquite occurs. The various red to magenta tones (background) of associated herbaceous vegetation also hinder the detection of redberry juniper in the July photograph.

Qualitative analysis and ground truth reconnaissance of additional color-infrared photographs acquired of 13 scattered rangeland areas near San Angelo, Justiceburg, Dickens, and Quanah in February 1999 showed that redberry juniper could be readily distinguished at all locations. It had a similar color-infrared image response to that shown in Figure 2B and could be distinguished at various photographic scales $(1: 1,200$ to $1: 8,500)$, but the best scales were $1: 1,200$ to $1: 6,000$. Redberry juniper could not be readily distinguished from honey mesquite in colorinfrared photographs obtained in June and July 1998, and June, July, and September 1999 at San Angelo, Justiceburg, Dickens, and Quanah. The inability to separate redberry juniper from honey mesquite during the growing season was attributed to their comparable visible reflectance values (Table 2).

The unsupervised computer classification of the February color-infrared photograph (Fig. 2B) is shown in Figure 2C. Color codes and respective areas/percentages for the various land-use types are: red $=$ redberry juniper $(29.9 \%)$, yellow $=$ mixed vegetation $(39.2 \%)$, green $=$ dormant honey mesquite $(15.5 \%)$, and white = bare soil $(15.4 \%)$. Mixed herbaceous species, tobosa grass, yucca, and plains prickly pear were included in the mixed vegetation class. All of these species and mixtures had similar NIR reflectance in February (Table 2). Shadow was not a problem in the classification. This was primarily attributed to obtaining the aerial photographs at mid-day. The generally short stature $(<3 \mathrm{~m})$ of the woody species also contributed minimal shadowing problems in the photographs. A qualitative comparison of the computer classification to the photograph shows that the computer did a good job in identifying redberry juniper. This technique can provide a means of quantifying redberry juniper infestations.

Table 3. An error matrix generated from classification data and ground data for the 23 February 1999 color-infrared photograph of the Justiceburg study site.

\begin{tabular}{lcccccc}
\hline \hline & \multicolumn{5}{c}{ Actual Category } & \\
\cline { 2 - 5 } Classified & Juniper & Mesquite & $\begin{array}{c}\text { Mixed } \\
\text { Vegetation }\end{array}$ & Bare Soil & Total & $\begin{array}{c}\text { User's } \\
\text { Accuracy }\end{array}$ \\
\hline Juniper & 30 & 0 & 0 & 0 & 30 & $100 \%$ \\
Mesquite & 1 & 8 & 7 & 0 & 16 & $50.0 \%$ \\
Mixed Vegetation & 1 & 1 & 37 & 0 & 39 & $94.9 \%$ \\
Bare Soil & 0 & 0 & 1 & 14 & 15 & $93.3 \%$ \\
\hline Total & 32 & 9 & 45 & 14 & 100 & \\
Producer's Accuracy & $93.8 \%$ & $88.9 \%$ & $82.2 \%$ & $100 \%$ & & \\
\hline
\end{tabular}

Overall accuracy $=89.0 \%$. Kappa $=0.841$.

Table 3 shows the error matrix by comparison of the classified data with the ground data for the 100 observations within the Justiceburg study area for the 23 February 1999 image. The overall classification accuracy was $89 \%$, indicating that $89 \%$ of the category pixels in the image were correctly identified in the classfication map. The user's accuracy ranged from $50 \%$ for honey mesquite to $100 \%$ for redberry juniper, whereas the producer's accuracy for individual categories ranged from $82.2 \%$ for mixed vegetation to $100 \%$ for bare soil. Redberry juniper was the easiest class to identify due to its distinct image response. The lower accuracy of honey mesquite was due to its confusion with mixed vegetation. The inability to separate defoliated honey mesquite plants from mixed vegetation was attributed to their similar image tonal responses. Another accuracy measure, the kappa estimate for this study, was 0.841 , indicating the classification has achieved an accuracy that is $84.1 \%$ better than would be expected from random assignment of pixels to the categories.

An accuracy assessment performed on the classification map of the 29 July 1999 color-infrared photograph of the Justiceburg study area had an overall accuracy of $54 \%$. Both the producer's accuracy and user's accuracy were lower for the 4 categories, compared to the 23 February 1999 classification map. As for the ability to classify redberrry juniper, the 29 July classification resulted in a producer's accuracy of $87.5 \%$ and a user's accuracy of $50 \%$. In other words, although $87.5 \%$ of the redberry juniper areas were correctly identified as redberry juniper, only $50 \%$ of the areas called redberry juniper were actually redberry juniper. The low accuracy was primarily due to significant confusion in discriminating redberry juniper from honey mesquite and mixed vegetation as revealed on the July 29 photograph (Fig. 2A).

\section{Conclusions}

Our results indicate that color-infrared aerial photography can be a useful tool for distinguishing redberry juniper infestations on the Texas Rolling Plains in winter due to its evergreen foliage. Other associated plant species that are confused with redberry juniper during the growing season are dormant during winter. Ground reflectance measurements support these findings. The optimum photographic scales for distinguishing redberry juniper were $1: 1,200$ to $1: 6,000$. Computer image analysis of a color-infrared film transparency $(1: 5,000$ scale) obtained in February showed that redberry juniper infestations could be differentiated quantitatively from associated vegetation and soil. An accuracy assessment of the classification showed that the user's accuracy was $100 \%$ and the producer's accuracy was $93.8 \%$ for redberry juniper. The capability to remotely distinguish redberry juniper infestations on rangelands should be useful to range resource managers who are interested in infestation monitoring and control of noxious woody plants on rangelands. Aerial photographs provide a record that can be stored and examined for comparative purposes at any time and provide the highest resolution and capture the spatial essence of the scene with greater fidelity than any other procedure. Disadvantages of aerial photography include cost of repeated coverage for change detection, costs of film and processing, and the limited spectral sensitivity (Tueller 1989).

\section{Literature Cited}

Anderson, G. L., C. W. Prosser, S. Haggar, and B. Foster. 1999. Change detection of leafy spurge infestations using aerial photography and geographic information systems, pp. 223-230. In: P. T. Tueller (ed.), Proc. $17^{\text {th }}$ Biennial Workshop Color Aerial 
Photography and Videography in Resource Assessment. Amer. Soc. Photogrammetry and Remote Sensing, Bethesda, Md.

Ansley, R. J., W. E. Pinchak, and D. N. Ueckert. 1995. Changes in redberry juniper distribution in northwest Texas (1948 to 1982). Rangelands 17:49-53.

Bowers, S. A. and R. J. Hanks. 1965. Reflection of radiant energy from soils. Soil Sci. 100:130-138.

Correll, D. S. and M. C. Johnston. 1979. Manual of the vascular plants of Texas. University of Texas Printing Division, Austin, Tex. 1881 p.

Driscoll, R. S., J. H. Everitt, R. Haas, and P. T. Tueller. 1997. Ranges and range management, pp. 441-474. In: W. R. Philipson (ed.) Manual of Photographic Interpretation. Amer. Soc. Photogrammetry and Remote Sensing, Bethesda, Md.

Ellis, D. and J. L. Schuster. 1968. Juniper age distribution on an isolated butte in Garza County, Texas. Southwest. Natur 13:343-348.

Erdas, Inc. 1997. Erdas-Imagine V8.3 tour guide. Erdas, Inc. Atlanta, Ga.

Everitt, J. H., D. E. Escobar, and M. R. Davis. 1995. Using remote sensing for detecting and mapping noxious plants. Weed Abst. 44:639-649.

Everitt, J. H., A. J. Richardson, and P. R. Nixon. 1986. Canopy reflectance characteristics of succulent and nonsucculent rangeland plant species. Photogrammetric Eng. and Remote Sensing 52:1891-1897.

Everitt, J. H., M. A. Alaniz, D. E. Escobar, and M. R. Davis. 1992. Using remote sensing to distinguish common (Isocoma coronopifolia) and Drummond goldenweed (Isocoma drummondii). Weed Sci. 40:621-628.

Gausman, H. W. 1974. Leaf reflectance of near-infrared. Photogrammetric Eng. 40:183-191.
Gausman, H. W. 1985. Plant leaf optical properties in visible and near-infrared light. Graduate Studies Texas Tech University, No. 29. Texas Tech Univ. Press, Lubbock, Tex. $78 \mathrm{p}$.

Gausman, H. W., R. M. Menges, D. E. Escobar, J. H. Everitt, and R. L. Bowen. 1977. Pubescence affects spectra and imagery of silverleaf sunflower (Helianthus argophyllus). Weed Sci. 25:437-440.

Gerbermann, A. H., C. L. Wiegand, A. J. Richardson, and R. R. Rodriguez. 1987. Diurnal soil reflectance in the 450 - to 2450 $\mathrm{nm}$ interval as related to photographic and video sensing, pp. 184-195. In: J. H. Everitt (ed.), Proc. $11^{\text {th }}$ Biennial Workshop Color Aerial Photography and Videography in the Plant Sciences. Amer. Soc. Photogrammetry and Remote Sensing, Bethesda, Md.

Hatch, S. L., H. N. Gandhi, and L. E. Brown. 1990. Checklist of the vascular plants of Texas. MP-1655. Tex. Agr. Exp. Sta., Texas A\&M Univ., College Station, Tex. 158 p.

Myers, V. I., M. E. Bauer, H. W. Gausman, W. G. Hart, J. L. Heilman, R. B. McDonald, A. B. Park, R. A. Ryerson, T. J. Schmugge, and F. C. Westin. 1983. Remote sensing in agriculture, $\mathrm{pp}$. 2111-2228. In: R. N. Colwell (ed.), Manual of Remote Sensing, Amer. Soc. Photogrammetry and Remote Sensing, Falls Church, Virg.

Myhre, R. J. 1987. Application of aerial photography to several new and unusual vegetation pest problems, pp. 49-53. In: C. E. Olson (ed.), Proc. 10 $10^{\text {th }}$ Biennial Workshop Color Aerial Photography in the Plant Sciences. Amer. Soc. Photogrammetry and Remote Sensing, Falls Church, Virg.

Richardson, A. J. 1981. Measurement of reflectance factors under daily and intermittent irradence variations. Appl. Optics 20:1336-1340.
Robinson, B. F., M. E. Bauer, D. P. DeWitt, L. F. Silva, and V. C. Vanderbilt. 1979. Multiband radiometer for field use. Measurements of Optical Radiations, SPIE Vol. 196, SPIE, Bellingham, Wash. p. 8-15.

Scifres, C. J. 1980. Brush management. Texas A\&M Univ. Press, College Station., Tex. 360 p.

Smeins, F. E. 1980. Natural role of fire in the Edwards Plateau, p. 4-16. In: L. D. White (ed.), Prescribed Burning on the Edwards Plateau of Texas. Tex. Agr. Ext. Serv., College Station, Tex.

Smeins, F. E. 1990. Ashe juniper:consumer of Edwards Plateau rangeland. Tex. Agr. Exp. Sta. Tech Rep. No. 90:1, Sonora Res. Sta., Sonora, Tex.

Steel, R. G. D. and J. H. Torrie. 1980. Principles and procedures of statistics. McGraw-Hill, New York, N. Y. 481 p.

Steuter, A. A. and C. M. Britton. 1983. Fireinduced mortality of redberry juniper (Juniperus pinchotti Sudw.). J. Range Manage. 36:343-345.

Steuter, A. A. and H. A. Wright. 1983. Spring burning effects on redberry juniper-mixed grass habitats. J. Range Manage. 36:161-164.

Tueller, P. T. 1982. Remote sensing for range management, pp. 125-140. In: C. J. Johannsen and J. L. Sanders (eds.), Remote Sensing for Resource Management. Soil Conserv. Soc. Amer., Ankeny, Iowa.

Tueller, P. T. 1989. Remote sensing technology for rangeland management. J. Range Manage. 42:442-453.

West, N. E. 1991. Junipers of the western U.S.: Classification, distribution, ecology, and control, pp. 325-333. In: L. F. James, J. Evans, M. H. Ralphs, and R. D. Child (eds.), Noxious Range Weeds. Westview Press, Boulder, Colo. 